\title{
KONSEP MONOPOLI DALAM TINJAUAN BISNIS ISLAM
}

\author{
Eka Junila Saragih \\ Fakultas Syariah dan Ekonomi Islam IAIN Pontianak \\ Email: ekasaragih36@gmail.com
}

\begin{abstract}
In Islam, monopoly is called as Ihtikar or treasuring act. This act is banned since it has negative effect on supply of goods that can lead market instability and distortion. Generally, government may impose monopoly that includes three elements: water, grass, and fire. It is a juridical normative library research on the act of monopoly conducted by big companies such as PT. Indofood. Monopoly can cause negative and positive effects to society. According to Islam, the main goal of economy is gaining big social benefits, so that any act against the principle is beyond Islamic teaching. Further, monopoly and speculation do not fit the poor and even contradict sharia due to the higher price affected by the act. According to law concerning business in Indonesia No. 5 of 1999, the act of monopoly is forbidden, while based on Islamic perspective, monopoly is permitted as long as there is no ihtikar or treasuring, especially of staple foods. Thus, government has an important role to control monopoly by dismissing treasuring act.
\end{abstract}

Keywords: Concept, Monopoly, Islamic Business.

\begin{abstract}
Abstrak
Monopoli dalam islam disebut ihtikar yaitu perilaku menimbun . Perilaku ini dilarang karena akan berpengaruh negatif terhadap jumlah barang yang tersedia sehingga ketersediaan dan permintaan barang menjadi tidak stabil, terjadi distorsi pasar. Secara umum, monopoli oleh negara tertuju dalam tiga hal yaitu air, rumput dan api. Penelitian ini menggunakan yuridis normatif, bahan-bahan yang dikumpulkan dengan studi kepustakaan. Penelitian ini membahas perilaku tindakan monopoli. Tindakan tersebut dilakukan oleh para perusahaan besar seperti PT. Indofood. Eksitensi monopoli dalam suatu kegiatan ekonomi dapat terjadi dalam berbagai jenis, ada yang merugikan dan ada yang menguntungkan perekonomian dan masyarakat. Dalam perekonomian Islam yang terpenting ialah keinginan untuk mencapai keuntungan sosial yang sebanyak-banyaknya. Oleh sebab itu, setiap kegiatan ekonomi yang mungkin merintangi tujuan ini tidak dapat dinyatakan bersifat islami. Apabila dilihat dari norma kebajikan dan pemeliharaan untuk golongan miskin tidak mungkin kita menganjurkan usaha monopoli dan spekulatif dalam Islam. Pada umumnya, pelaku monopoli menetapkan harga yang lebih tinggi untuk hasil produksinya. Maka eksploitasi sangat berhubungan dengan gagasan monopoli. Dalam pandangan hukum bisnis di Indonesia, praktik monopoli ini dilarang. Hal ini tertuang dalam undangundang No. 5 tahun 1999. Dalam pandangan hukum islam monopoli boleh dilakukan asalkan tidak melakukan penimbunan atau ihtikar. Terutama praktik ikhtikar pada bahan makanan pokok. Di sini terlihat jelas betapa pentingnya peran
\end{abstract}


pemerintah untuk menekan monopoli dengan melakukan berbagai upaya menghilangkan penimbunan.

Kata Kunci: Konsep, monopoli, bisnis Islam.

\section{Pendahuluan}

Monopoli merupakan masalah yang menjadi perhatian utama dalam setiap pembahasan pembentukan hukum persaingan usaha. Akan tetapi perlu diingat bahwa sekalipun demikian, monopoli itu sendiri pada dasarnya bukanlah suatu bentuk kejahatan atau bertentangan dengan hukum apabila diperoleh dengan caracara yang fair dan tidak melanggar hukum monopoli baru dilarang. Apabila perusahaan yang memiliki monopoli itu melakukan monopolisasi.

Penentu harga pada pasar ini yaitu seorang penjual atau "monopolis". Seorang monopolis dapat menaikkan atau mengurangi harga dengan cara menentukan jumlah barang yang akan diproduksi. Semakin sedikit barang yang diproduksi maka semakin mahal harga barang tersebut. begitu pula sebaliknya. Walaupun demikian penjual juga memiliki suatu keterbatasan dalam penetapan harga. Apabila penetapan harga terlalu mahal, maka orang akan menunda pembelian dan berusaha mencari membuat barang substitusinya.

Persoalan monopoli sesungguhnya merupakan persoalan yang sangat menarik untuk dibahas. Bahkan permasalahan ini telah mendapat perhatian yang sangat serius dari ajaran Islam, sebagaimana yang dinyatakan oleh Allah Swt: “...kay lã yakûna dûlatun baina al-aghniyã’i minkum...”

"...agar harta itu jangan hanya berputar di kalangan orang-orang kaya di antabnra kamu sekalian..." (QS Al-Haysr ayat 7)..

Selain riba, monopoli adalah komponen utama yang akan membuat kekayaan terkonsentrasi di tangan segelintir kelompok, sehingga menciptakan kesenjangan sosial dan ekonomi. Para ulama terkemuka abad pertengahan pun, seperti Ibn Taimiyyah, Ibn al-Qayyim al-Jauziyyah, dan Ibn Khaldun, telah pula 
melakukan kajian yang mendalam tentang praktik monopoli. Ibn Taimiyyah ${ }^{1}$ misalnya, dalam kitabnya Al-Hisbah fil Islam menyatakan bahwa ajaran Islam sangat mendorong kebebasan untuk melakukan aktivitas ekonomi sepanjang tidak bertentangan dengan aturan agama. Kepemilikan dan penguasaan aset kekayaan di tangan individu adalah sesuatu yang diperbolehkan dalam Islam. Namun demikian, ketika kebebasan tersebut dimanfaatkan untuk menciptakan praktikpraktik monopolistik yang merugikan, maka adalah tugas dan kewajiban negara untuk melakukan intervensi dan koreksi.

\section{Kegiatan Monopoli}

Dalam UU No. 5 Tahn 1999, pengertian monopoli dibedakan dari praktik monopoli. Pengertian "praktik monopoli” dikemukakan dalam Pasal 1 angka 2 UU No.5 Tahun 1999, yaitu pemusatan kegiatan ekonomi oleh satu atau lebih pelaku usaha yang mengakibatkan dikuasainya produksi dan/atau pemasaran atas barang dan/atau jasa tertentu, sehingga menimbulkan persaingan usaha tidak sehat dan dapat merugikan kepentingan umum. ${ }^{2}$

Dari definisi tersebut dapat dilihat bahwa monopoli yang tidak mengakibatkan persaingan usaha tidak sehat dan tidak merugikan kepentingan umum tidak dilarang, yang dilarang berdasarkan UU adalah praktik monopoli dan persaingan usaha tidak sehat. Sedangkan pengertian monopoli dalam pasal 1 angka 1 UU No.5 Tahun 1999 adalah suatu penguasaan atas produksi dan/atau pemasaarn barang dan/atau jasa tertentu oleh satu pelaku usaha atau satu kelompok pelaku usaha.

Istilah monopoli dalam terminologi Islam tidak ditemukan secara konkrit namun dalam muamalat terdapat satu ungkapan yang disinyalir "hampir mirip" dengan monopoli yaitu al-Ihtikar. Al-Ihtikar merupakan bahasa Arab yang definisinya secara etimologi ialah perbuatan menimbun, pengumpulan. Secara sederhana, ihtikar dapat diartikan sebagai upaya membatasi pasokan barang agar dapat menjual barang dengan harga yang lebih tinggi. Dengan kata lain, membeli

\footnotetext{
${ }^{1}$ Ibn Taimiyah, Al-Hisbah fil Islam, dikutip dalam Nasroen Harun, Fiqh Muamalah, (Jakarta: Gaya Media Pratama, 2000). hlm.58

2 Pasal 17, Pasal 1 huruf c, UU No. 5 Tahun 1999
} 
barang dagangan dan mengumpulkannya dari pasar pada saat langka kemudian dijual kembali pada saat masyarakat membutuhkan barang tersebut dengan keuntungan yang berlipat.

Perilaku ini dilarang karena akan berpengaruh negatif terhadap jumlah barang yang tersedia sehingga ketersediaan dan permintaan barang menjadi tidak stabil, terjadi distorsi pasar. Larangan melakukan penimbunan dapat dilihat dalam beberapa hadis Rasulullah saw:

“Manihtakara arba’îna yauman faqad barià minallahi wa bariàllahu minhum”.

"barang siapa menimbun bahan makanan selama empat pulu malam, maka sesungguhnya ia telah berlepas diri dari Allah, dan Allahpun berlepas darinya". ${ }^{3}$

Berkata Ali ra.: Barang siapa memonopoli bahan makanan selama 40 hari, niscaa hatinya menjadi keras.

Sebabnya adalah karena ia hanya memperhatikan kepentingan diri sendiri dan tidak menghiraukan bahaya yang menimpa masyarakat. Setiap kali terjadi penurunan harga, dia merasa sakit dan menderita. Tetapi setiap kali mendengar kenaikan harga, dia merasa senang dan gembira. Karena itu, tidak ayal lagi rasa kasih sayang pasti akan hilang dari hatinya dan terjangkiti oleh egoisme dan kesesatan hati. Kesesatan hati merupakan bencana yang mencampakkan manusia dari ketinggian martabat kemanusiaan kepada lembah kebinatangan dan kebuasan.

Sebab utama tindakan monopoli adalah egoisme dan kesesatan hati terhadap hamba Allah. Karena orang yang mempraktekkan monopoli ingin meluaskan kekayaannya dengan cara mencekik makhluk Allah, membangun istana-istananya dari tempurung-tempurung kepala manusia dan menghisap darah mereka untuk dialirkan pada nadinya dengan maksud mengeruk ribuan dan jutaan uang kedalam rekening simpanannya.

“Manihtakara fahuwa khãthiûn”.

"barang siapa menimbun maka dia telah berbuat dosa". 4

${ }^{3}$ HR. Ahmad, Hakim dan Ibn Syaibah dikutip dari Mustafa Kamal Rokan, Hukum Persaingan Usaha (Teori dan praktiknya di Indonesia), Jakarta: Rajawali Press,2010. hlm. 42

${ }^{4}$ HR. Muslim, Ibid 
Sejelek-jelek manusia ialah orang yang suka menimbun, jika mendengar harga murah merasa kecewa dan jika mendengar harga naik, ia merasa gembira. ${ }^{5}$

Yusuf Al-Qardhawi mengatakan tindakan ihtikar diistilahkan dengan monopoli, yakni menahan barang untuk tidak beredar di pasar agar harganya menjadi naik. ${ }^{6}$ Lebih dari itu, semau jenis barang yang dilarang ditimbun selama penimbunan tersebut akan berdampak kepada stabilitas pasar. $^{7}$

Istilah penimbunan barang dalam hadis di atas harus dipahami sebagai dampak dari sebuah perilaku. Perilaku menimbun barang yang dinyatakan bersalah jika perbuatan penimbunan akan berakibat naiknya harga barang di pasar. Dengan kata lain penimbunan yang dilakukan oleh pelaku usaha dalam rangka menaikkan harga pasar dan setelah itu akan menjual barangnya dengan harga yang tinggi untuk meraup keuntungan yang banyak. Jadi tidak termasuk ihtikar jika penumpukan barang dilakukan pada saat pasokan berlebih seperti saat panen besar, sebab tidak berdampak terhadap harga dan tidak merugikan konsumen.

Islam melarang keras melakukan pemusatan produksi yang akan menyebabkan keuntungan hanya diperoleh oleh orang-orang tertentu saja. Pemusatan kekayan akan menjadikan ekonomi, sosial dan politik dalam masyarakat menjadi tidak seimbang. Islam juga sangat menghormati kemampuan pelaku usaha tertentu untuk mendapatkan keuntungan yng besar dalam perniagaannya selama tidak melakukan pemusatan ekonomi yang menyebabkan keuntungan hanya diperoleh beberapa orang.

Dalam kebijakan ekonomi Negara, Rasulullah saw. Pernah melakukan kebijakan ekonomi ketika hanya terdapat satu golongan yang kaya di negeri itu, namun disaat yang sama kemiskinan terjadi dimana-mana. Sebagai kepala Negara, Rasulullah melakukan penetrasi pasar pada saat pertama kali menaklukan nazir

\footnotetext{
${ }^{5}$ HR. Ibn Razih, Ibid.

${ }^{6}$ Yusuf Qardhawi, 1997. Peran Nilai dan Moral dalam Perekonomian Islam (Terjemahan), Jakarta: Robbani Press, hlm. 321.

${ }^{7}$ Terdapat dua pendapat ulama tentang jensi barang yang dilarang ditimbun (ihtikar). Imam Syafi'i membolehkan penimbunan barang dagangan selain makanan pokok, sedangkan Imam Malik berpendapat semua jenis barang. (Syarh muslim, 11:43, dan Muslim 3:1228 yang dikutip dari Ash-Shadiq Abdurrahman, . Ftawa-fatwa Muamalah Kontemporer, (Surabaya: Pustaka Progressif,2004) hlm. 48
} 
dengan cara memberi seluruh kekayaan fa'i yang diperolehnya kepada kaum Muhajirin dan Anshar. Dalam konteks ini, Nabi Saw, sangat menaati perintah AlQur'an dalam mendsitribusikan kekayaan. ${ }^{8}$

Secara umum, monopoli oleh negara tertuju dalam tiga hal yaitu air, rumput dan api. Hal ini berdasarkan hadis Rasulullah saw:

“orang-orang islam itu bersekutu (memiliki hak yang sama) dalam tiga hal yaitu rumput, air dan api." 9

Secara lebih luas bahwa pengertian tiga aset dalam hadis tersebut tentunya tidak dipahami secara kebahasaan. Ketiga aset tersebut merupakan simbol dari sesuatu yang menjadi hajat hidup orang banyak sehingga aset itu adalah kepentingan bersama, dengan kata lain, Rasulullah saw. melihat bahwa tiga aset tersebut merupakan simbol dari hidup manusia yang harus dijaga keberadaan, kelestarian, serta pengelolaannya oleh negara.

“Rumput” merupakan simbol dari apa-apa yang tumbuh dipermukaan bumi yang menjadi kepentingan hajat hidup orang banyak. Karenanya rumput dapat menjadi simbol dari kawasan hutan dan sebagainya. Demikian pula air. Air merupakan simbol energi yang berada di bawah tanah. Air adalah salah satu sumber kehidupan yang terpenting bagi manusia. Karena air adalah aset yang harus dijaga keberadaannya bagi negara. Negara wajib menjaga keberadaannya bagi kepentingan hidup orang banyak. Tidak hanya itu, air merupakan simbol dari seluruh energi yang berada di bawah tanah, seperti minyak, batu bara, gas dan sebagainya. Demikian pula “api” yang merupakan simbol “energi” yang berasal dari atas tanah, karenanya energi yang ada di atas tanah harus dijaga dan dikuasai oleh negara.

Oleh karena itu, sektor-sektor ekonomi seperti air (PAM ), listrik (PLN), telekomunikasi, kekayaan alam seperti minyak bumi, gas dan barang tambang lainnya harus dikuasai oleh negara untuk kepentingan rakyat dan tidak boleh dikuasai swasta sepenuhnya, karena itu merupakan tindakan monopoli. Monopoli

${ }^{8}$ Afzalur Rahman, 2009. Ensiklopedia, Muhammad Sebagai Pedang. Jakarta: Pelangi Mizan. Dikutip dari Mustafa Kamal Rokan, . Hukum Persaingan Usaha (Teori dan praktiknya di Indonesia), Jakarta: Rajawali Press.2010. hlm. 36

${ }^{9}$ HR. Abu Daud, Ibid. 
ini termasuk dalam monopoli karena perlindungan undang-undang. Yakni perusahaan-perusahaan diberikan hak monopoli berdasarkan amanah undangundang, sekalipun perusahaan tersebut tidak efisien.

Selain itu ada jenis monopoli yang terjadi secara alamiah. Monopoli alamiah adalah monopoli yang lahir karena mekanisme murni dalam pasar. Monopoli ini lahir secara wajar dan alamiah karena kondisi objektif yang dimiliki oleh suatu perusahaan, yang menyebabkan perusahaan ini unggul dalam pasar tanpa bisa ditandingi dan dikalahkan secara memadai oleah perusahaan lain. Dalam jenis monopoli ini, sesungguhnya pasar bersifat terbuka. Karena itu, perusahaan lain sesungguhnya bebas masuk dalam industri yang sama. Hanya saja, perusahaan lain tidak mampu menandingi perusahaan monopolistis tadi sehingga perusahaan yang unggul tadi relatif menguasai pasar dalam jenis industri tersebut.

Pelaku usaha menjadi "monopoli” disebabkan kelebihan yang dimilikinya secara alami. Biasanya, perusahaan tersebut memiliki beberapa hal sebagai berikut:

1. Memiliki kemampuan dan/ atau kemampuan khusus (special knowledge) yang memungkinkan berproduksi sangat efektif dan efisien.

2. Memiliki tingkat efisiensi memungkinkan perusahaan monopolis dapat meminimalisasi biaya.

3. Memiliki kemampuan kontrol sumber faktor produksi, baik berupa sumber daya alam, sumber daya manusia maupun lokasi produksi.

Dalam fenomena perekonomian indonesia, kelompok konglomerat di indonesia mempunyai kemampuan monopoli secara teknis, karena mampu mengontrol faktor produksi berupa bahan baku. Monopoli juga bisa terjadi jika produk yang dihasilkan mempunyai rasa kekhasan seperti dalam hal makanan atau gaya tertentu untuk produk pakaian. Dalam konteks ini, kekuatan monopoli disebut

Dalam sejarah, Rasulullah saw. Juga selalu melakukan "monopoli” sumbersumber ekonomi dalam rangka kepentingan umum. Sumber-sumber ekonomi Madinah tidak diberikan kepada kepemilikan pribadi, namun sebaliknya sumbersumber ekonomi yang menghidupi orang banyak yang melibatkan kepentingan 
umum harus dikuasai oleh negara dan dipergunakan sebesar-besarnya bagi kemakmuran rakyat. Saat itu, sumber ekonomi yang sangat dominan adalah tanah yang berisikan padang rumput sebagai tempat makanan binatang ternak. Demikian juga lokasi sumber garam, sumber air, dan sebagainya tidak diberikan kepemilikannya kepada pribadi.

Kebijakan ini jelas terlihat dalam kisah sahabat yang bernama Abyad bin Hammal. Awalnya Abyad menuntut diberikan satu bidang tanah di daerah ma'rib, kemudian Rasulullah saw. Mengabulkan permintaan itu. Namun seorang bernama Aqra’ bin Habis berdiri sambil bertanya kepada Rasulullah Saw. Adakah engkau tahu kondisi lokasi itu sebenarnya? Sembari menjelaskan bahwa kawasan itu adalah sumber air yang menghasilkan garam. Mendengar penjelasan tersebut, Rasulullah saw menarik kembali pemberian daerah yang telah diberikannya kepada Abyad bin Hammal. ${ }^{10}$

Demikian juga ketika Abyad bin Hammal mengajukan permohonan untuk memiliki tanah yang berisikan pohon Al-Arak (kayunya dapat dimanfaatkan sebagai kayu sugi). Rasulullah hanya mengizinkan daerah itu dengan syarat harus jauh dari tempat pemukiman penduduk pusat pasar Madinah. Sebab kawasan pinggiran Madinah adalah kawasan perumahan dan padang rumput sebagai tempat makanan hewan-hewan ternak.

Kisah di atas menggambarkan bagaimana Rasulullah Saw. Melakukan monopoli bagi sumber-sumber ekonomi yang merupakan hajat hidup orang banyak. Kebalikannya, Rasulullah menolak dilakukannya privatisasi (kepemilikan secara pribadi atau sekelompok orang) dari sumber-sumber ekonomi negara. Selain itu, kisah ini juga menunjukkan kedaulatan negara terhadap wilayah dan seluruh kekayaan yang terkandung didalamnya untuk digunakan sebesar-besarnya bagi kemakmuran rakyat. Sebaliknya, negara yang tidak berdaulat adalah negara dan kekayaannya dapat dimiliki oleh kepentingan pribadi ataupu korporasi.

Ibnu Taymiyah hanya membatasi keabsahan pemerintah dalam menetapkan kebijakan intervensi pada empat situasi: ${ }^{11}$

${ }^{10}$ HR. Abu Daud dan Imam Tirmidzi, Ibid. hlm. 38

${ }^{11}$ Mustafa Edwin Nasution Dkk, Ibid. hlm. 40. 
a. Kebutuhan masyarakat atau hajat orang banyak akan sebuah komoditas (barang maupun jasa). Para fuqaha speakat bahwa sesuatu yang menjadi hajat hidup orang banyak tidak dapat dijualbelikan kecuali dengan harga yang sesuai.

b. Terjadi monopoli (penimbunan). Para fuqaha sepakat memberlakukan ketetapan yang membatasi hak guna dan hak pakai atas kepemilikan barang oleh pemerintah. Hal ini untuk mengantisipasi adanya tindkan negatif atau bahaay yang dilakukan oleh pihak-pihak yang melakukan kegiatan monopolisik atau penimbunan barang.

c. Terjadi koalisis dan kolusi antara para penjual dimana sejumlah pedagang sepaakt untuk melakukan transaksi diantara mereka dengan harga penjualan yang tentunya di bawah harga pasar.

\section{Jenis Monopoli}

Pada dasarnya persaingan dalam dunia usaha merupakan suatu syarat mutlak bagi terselenggaranya suatu perekonomian yang berorientasi pasar (market economy). Peranan hukum dalam persaingan usaha adalah dari terselenggaranya suatu persaingan yang sehat dan adil, sekaligus mencegah munculnya persaingan yang tidak sehat (unfair competition) karena persaingan yang tidak sehat hanya akan bermuara pada matinya persaingan usaha yang pada gilirannya akan melahirkan monopoli. ${ }^{12}$

Eksitensi monopoli dalam suatu kegiatan ekonomi dapat terjadi dalam berbagai jenis, ada yang merugikan dan ada yang menguntungkan perekonomian dan masyarakatnya. Adapun jenis-jenis monopoli tersebut yaitu: ${ }^{13}$

\section{Monopoli yang terjadi karena Undang-undang}

Pasal 33 UUD 1945 menghendaki adanya monopoli Negara untuk menguasai bumi dan air berikut kekayaan alam yang terkandung didalamnya, serta cabang-cabang produksi yang menguasai hajat hidup orang banyak. Selain itu, Undang-undang juga memberikan hak istimewa dan perlindungan

\footnotetext{
12 Dalam daftar peristilahan yang disusun oleh organizatation for economic cooperation and development (OECD) definisi monopoli adalah: "situation where there is single seller in the market”. Dikutip dalam Johny Ibrahim, cet.3.2009. Hukum Persaingan Usaha Filosofi, Teori dan Implikasi Penerapannya di Indonesia. Malang: Bayu Media Publishing. Hlm. 40.

${ }^{13}$ Ibid, hlm.40
} 
hukum dalam jangka waktu tertentu terhadap pelaku usaha yang memenuhi syarat tertentu atas hasil riset dan inovasi yang dilakukan sebagai hasil pengembangan teknologi yang bermanfaat bagi manusia.

Pemberian hak-hak eklusif bagi penemuan baru, baik yang berasal dari hak atas kekayaan intelektual seperti hak cipta (copyright) dan hak atas kekayaan industry (industrial property) seperti paten, merek, desain produk industry, dan rahasia dagang pada dasarnya adalah merupakan bentuk lain monopoli yang diakui dan dilindungi oleh Undang-undang.

\section{Monopoli yang terjadi secara Alamiah}

Monopoli bukanlah merupakan suatu perbuatan yang jahat atau terlarang apabila kedudukan tersebut diperoleh dengan mempertahankan posisi tersebut melalui kemampuan prediksi dan naluri bisnis yang professional. Kemampuan sumber daya manusia yang professional, kerja keras, dan strategi bisnis yang tepat dalam mempertahankan posisinya akan membuat suatu perusahaan memiliki kinerja yang unggul (superior skill) sehingga tumbuh secara cepat dengan menawarkan suatu kombinasi antara kualitas dan harga barang dan jasa serta pelayanan sebagaimana dikehendaki konsumen.

Pelaku usaha atau perusahaan yang memiliki kinerja unggul seperti itu sering memiliki jurus-jurus rahasia dagang yang meskipun tidak mmeperoleh hak eklusif dan pengakuan dari Negara, namun dengan teknologi rahasianya tersebut, mampu menempatkan posisinya sebagai perusahaan monopoli.

\section{Monopoli yang diperoleh melalui lisensi dengan menggunakan Mekanisme}

\section{Kekuasaan}

Monopoli seperti ini dapat terjadi karena adanya kolusi antara para pelaku usaha dengan birokrat pemerintah. Kehadirannya menimbulkan distorsi ekonomi karena mengganggu bekerjanya mekanismepasar yang efisien. Umunya monopoly by license berkaitan erat dengan para pemburu rente ekonomi (rent seekers) yang mengganggu keseimbangan pasar untuk kepentingan mereka. Berbagai kelompok usaha yang dekat dengan pusat kekuasaan dalam pemerintahan pada umumnya memiliki kecendrungan 
melakukan perbuatan-perbuatan tercela seperti itu, meskipun tidak semuanya memiliki rent seeking behavior.

Perbuatan rente sangat mencederai semangat persaingan usaha karena dianggap sebagai bisnis banci dan tanpa resiko. Dengan jaminan lisensi yang diperoleh dari pemerintah, mereka tinggal menunggu laba yang masuk.

\section{Monopoli karena terbentuknya Struktur Pasar Akibat Perilaku dan Sifat} serakah Manusia

Unsur-unsur yang mempengaruhi perilaku para pelaku usaha dalam praktik bisnis sehari-hari adalah sedapat-dapatnya menghindari munculnya pesaing baru. Karena munculnya pesaing atau rivalitas dalam berusaha akan menurunkan tingkat keuntungan. Hal ini dapat terjadi karena keputusan tentang kualitas, kuantitas, dan kebijakan harga tidak lagi ditentukan oleh satu pelaku usaha atau satu perusahaan saja, tetapi juga dipengaruhi oleh paar pesaingnya.

Praktik bisnis yang bersifat antipersaingan dan tidak jujur tersebut dapat dilakukan secara sendiri atau bekerja sama dengan para pelaku usaha lainnya. Jelasnya, monopoli yang menghambat persaingan adalah monopoli yang melakukan penyimpangan struktur pasar karena menyebabkan terjadinya pembentukan pasar, pembagian pasar, dan menyalahgunakan kekuatan pasar (market power) guna menyingkirkan para pesaing keluar dari arena pasar.

Setelah para pesaing tersingkir dari arena, dengan sesukanya para pelaku usaha tersebut melakukan kontrol atas harga. Pada jenis monopoli seperti itu, konsumen akan sangat dirugikan karena tidak lagi memiliki alternatif lain pada saat akan membeli barang atau jasa tertentu dengan kualitas yang andal serta harga yang wajar dan bersaing. Kondisi seperti itu akan melahirkan inefisiensi ekonomi dan memiliki potensi pemborosan sumber daya, terutama sumber daya alam. Kerugian masyarakat tersebut disebut dead weight loss. 


\section{Fakta-fakta Penyebab Monopoli}

Perusahaan tidak memiliki pesaing karena adanya hambatan (barriers to entry) bagi perusahaan lain untuk memasuki industri yang bersangkutan. Dilihat dari penyebabnya, hambatan masuk dikelompokkan menjadi dua yaitu: ${ }^{14}$

\section{Hambatan Teknis (Technical Barriers to Entry)}

Ketidakmampuan bersaing secara teknis menyebabkan perusahaan lain sulit bersaing dengan perusahaan yang sudah ada (existing firm). Keunggulan secara teknis ini disebabkan oleh beberapa hal:

a) Perusahaan memiliki kemampuan dan/atau pengetahuan khusus yang memmungkinkan untuk berproduksi secara sangat efisien.

b) Tingginya tingkat efisiensi memungkinkan perusahaan monopolis mempunyai kurva biaya (MC dan AC) yang menurun. Makin besar skala produksi, biaya marginal semakin menurun, sehingga biaya produksi per unit (AC) semakin rendah (decreasing MC dan $\mathrm{AC}$ ).

c) Perusahaan memiliki kemampuan control sumber factor produksi, baik berupa sumber daya alam, sumber daya manusia maupun lokasi produksi.

Kelompok konglomerat di Indonesia mempunyai kemampuan monopoli seara teknis, karena mampu mengontrol faktor produksi berupa bahan baku (misalnya batu kapur untuk pabrik semen). Selain bahan baku, faktor produksi yang dimonopoli konglimerat adalah SDM berkualitas, dimana tamatantamatan universitas top di Indonesia kebanyakan bekerja di perusahaan konglomerat disbanding perusahaan kecil. Lokasi perusahaan yang khusus juga menyebabkan perusahaan memiliki kemampuan teknis (biaya transportasi sangat rendah) yang menyebabkan daya monopoli.

Perusahaan-perusahaan yang mempunyai kekuatan monopoli karena kemampuan teknis disebut perusahaan monopolis alamiah. Monopli alamiah juga bisa terjadi jika penjual mempunyai kekhususan tersendiri dalam jenis barang atau jasa yang diproduksinya. Misalnya berupa rasa dan selera tertentu untuk makanan atau gaya tertentu untuk produk pakaian.

\footnotetext{
${ }^{14}$ Prathama Raharja dan Mandala Manurung, hlm. 231-232 dikutip dari Susanti Adi Nugroho, SH. MH, 2012, Hukum Persaingan Usaha di Indonesia, Jakarta: Kencana. hlm. 240
} 


\section{Hambatan Juridis (Legal Barriers to Entry)}

\section{a) Undang-undang dan hak khusus}

Tidak semua perushaan mempunyai kekuatan monopoli karena kemampuan teknis. Dalam kehidupan sehari-hari kita menemukan perusahaan-perusahaan yang tidak efisien tetapi memiliki daya monopoli. Hal itu dimungkinkan karena secara hukum mereka diberi hak monopoli . di Indonesia, Badan Usaha Milik Negara (BUMN) banyak memiliki kekuatan monopoli karena undang-undang. Berdasarkan undang-undang tersebut mereka memiliki hak khusus untuk mengelola industri tertentu.

Hak khusus tidak hanya diberikan pemerintah, tetapi juga oleh satu perusahaan lainnya. Di Indonesia beberapa bentuk konkretnya adalah agen tunggal, importer tunggal, lisensi dan waralaba. Itulah sebabnya dapat kita pahami bahwa tidak semua rumah makan boleh menjual Kentucky fried Chicken, atau Mc Donald.

\section{b) Hak paten atau hak cipta}

Tidak semua monopoli berdasarkan hukum atau undang-undang mengakibatkan inefisiensi. Hak Paten dan Hak Cipta adalah monopoli berdasarkan hukum karena mempunyai kemampuan pengetahuan khusus yang menciptakan dyaa monopoli secara teknik. Berdasarkan uraian-uraian di atas, industry penyediaan listrik (industry listrik) di Indonesia, dikatakan berstruktur pasar monopoli, karena:

1. Hanya ada satu produsen, yaitu Perusahaan Listrik Negara (PLN).

2. Listrik yang dihasilkan PLN tidak mempunyai substitusi, walaupun sumber tenaga listriknya memiliki beberapa alternatif (diesel, tenaga air, tenaga uap, dan nuklir).

3. Perusahaan-perusahaan lain tidak dapat memasuki industry listrik karena ada hambatan yaitu hak monopoli PLN berdasarkan undangundang.

Adapun monopoli yang dianggap bertentangan dengan kepentingan umum, apabila: 
1. Monopoli diberikan kepada satu atau beberapa perusahaan swasta tertentu saja antara tanpa melalui undang-undang.

2. Monopoli atau kedudukan monopolistik diperoleh dari kerja sama antara dua atau lebih organisasi sejenis baik dalam bentuk pengaturan persaingan di antara mereka sendiri maupun bentuk peleburan (fusi).

Menurut pendapat Kwik Kian Gie kondisi monopolistik sebagian besar terjadi karena peran Negara yang memberikan kondisi monopolistik kepada suatu usaha, baik usaha Negara, usaha swasta maupun koperasi (terjadi pada zaman orde baru). ${ }^{15}$

\section{Pengharaman Monopoli}

Para fuqaha berbeda pendapat tentang dua masalah:

\section{Jenis barang yang haram dimonopoli}

Sebagian fuqaha melarang monopoli hanya terhadap bahan makanan. Menurut Al-Ghazali ${ }^{16}$, barang-barang yang bukan makanan atau penunjang bahan makanan seperti obat, ramuan obat-obatan, kunyit, dan lain-lain tidak dilarang. Adapun bahan-bahan penunjang bahan makanan seperti daging, buahbuahan masih dalam pertimbangan. Diantara ulama ada yang menolak pengharaman monopoli terhadap samin, keju, madu dan minyak. Tidak seperti pada masa lalu, obat-obatan pada masa kini adalah bagian primer dalam kehidupan manusia. Begitu juga halnya dengan pakaian dan lainnya. Maka disamping membutuhkan makanan, manusia juga membutuhkan pakaian.

Alasan pelarangan monopoli ialah tindakan ini mendatangkan gangguan sosial. Bahaya itu timbul dari penahanan komoditi. Karena kebutuhan manusia bukan hanya pada makanan, tetapi juga minuman, pakaian, perumahan, pendidikan, pengobatan, transportasi, menurut Yusuf Qardhawi maka untuk mengikuti jejak Abi Yusuf yang berkata: ”setiap benda yang apabila ditahan (ditimbun) menyebabkan gangguan bagi manusia adalah monopoli. Dan setiap

\footnotetext{
${ }^{15}$ Kwik Kian Gie, Saya bermimpi jadi konglomerat, (Jakarta: PT.Gramedia 1994), Ibid hlm.242.

${ }^{16}$ Dikutip dalam Yusuf Qardhawi, 1997. Norma dan Etika Ekonomi Islam, Jakarta: Gema Insani Press, hlm. 191.
} 
bertambah butuhnya manusia kepada sesuatu barang yang dimonopoli maka dosanya semakin besar terutama makanan yang merupakan kebutuhan yang sangat pokok. ${ }^{17}$

\section{Waktu tidak dibolehkannya praktik monopoli}

Demikian pula tentang waktu diharamkannya monopoli. Diantara para ulama ada yang menolak pelarangan disemua waktu tanpa membedakan kesempitan dan kelonggaran waktu, berdasarkan keumuman larangan dan praktik-praktik monopoli. Al-Ghazali mengatakan dan boleh jadi pelarangan monopoli tersebut dikhususkan pada waktu persediaan bahan makanan yang sangat sedikit sementara orang-orang sangat membutuhkannya, sehingga tindakan menangguhkan penjualannya akan menimbulkan bahaya.

Namun jika bahan makanan berlimpah ruah dan orang-orang tidak membutuhkan dan menginginkannya kecuali dengan harga yang rendah, kemudian pemilik bahan makanan menunggu perubahan kondisi itu dan tidak menunggu paceklik. Maka tindakan ini tidak termasuk tindakan yang membahayakan tersebut. Jika masanya adalah masa paceklik dan dalam penimbunan madu, lemak, dan sebagainya terdapat unsur yang membahayakan, maka sepatutnya diputuskan untuk dilarang (diharamkan). Penetuan haram tidaknya tindakan menangguhkan penjualan bahan makanan pokok dikembalikan kepada ada tidaknya unsur membahayakan ini karena ia merupakan hal yang dipahami dari pengkhususan pelarangan monopoli bahan makanan.

Jika tidak ada unsur yang membahayakan, maka memonopoli bahan makanan pokok ini tidak luput dari hukum makruh karena ia menantikan prinsip-prinsip bahaya yaitu kenaikan harga. Menantikan prinsip-prinsip bahaya (kenaikan harga) adalah terlarang seperti menantikan datangnya bahaya itu sendiri, tetapi tingkatannya lebih rendah. Menantikan datangnya bahaya itu sendiri dibawah tingkatan tindakan yang membahayakan secara langsung. Tingkat bahaya ini akan menentukan tingkat keharaman dan kemakruhan tindakan monopoli yang dilakukan.

\footnotetext{
${ }^{17}$ Ibid
} 


\section{Contoh Kasus :}

Berikut ini adalah contoh perkara Monopoli yang dilakukan oleh PT Indofood sukses Makmur. ${ }^{18}$

Diawali pengawasan yang dilakukan oleh KPPU terhadap 8 perusahaan yang menguasai pasar lebih dari 50\% di antaranya adalah PT Indofood Sukses Makmur dengan penguasaan mayoritas pasar produk mie instant. Perusahaan yang sejak awal go public pada tahun 1994 telah menyatakan diri sebagai produsen makanan olahan terkemuka di Indonesia, dengan strategi pemasaran sehingga mampu melakukan penetrasi pasar yang tinggi untuk produk-produk yang dihasilkan.

Bidang usaha, terutama Indofood Group adalah industry mie instant, yang diperkirakan oleh survey riset pemasaran SRI (dalam laporan SRI Audit Retail) bahwa perseroan tersebut memiliki pangsa pasar sebesar 90\% sehingga sisa pangsa pasar sekitar 10\% dimiliki oleh produk lain seperti “Salam Mie” yang diproduksi oleh PT Senttrafood. Indonusa, Corporation, “Gaga Mie” oleh PT Jakarana Tama, “Alhami” dan "Sentramie”, oleh PT Olagafood Sukses Mandiri, "Mie ABC Selera Pedas" dan "President Mie" oleh PT ABC Presiden Enterprises Indonesia.

PT Indofood menghasilkan lebih dari 140 produk makanan yang terdiri dari 5 kelompok yaitu: produk utama Indofood hingga kini adalah Mie Instant yang memberikan kontribusi sebesar 82,9\% terhadap seluruh penjualan bersih pada 1993. Selain itu, perseroan juga memproduksi mie segar (fresh noodles) dan mie snacks (snack noodles), walaupun jumlahnya masih relative kecil dibandingkan dengan produk mie instant.

Namun demikian terdapat beberapa kelompok pebisnis local, seperti Group Medco dan Olagafood yang mulai berhasil merebut pasar mie instant, sehingga pangsa pasar Indofood semakin kecil. Jika pada 1998 mereka masih

\footnotetext{
${ }^{18} \mathrm{http} / / /$ hndwibowo.blogspot.com/2008/06/monopoli-dalam-pandangan-islam.html
} 
menguasai 95\% pangsa pasar, tahun 2001 persentase tersebut sudah turun menjadi 88\% di tahun 2002. Meskipun PT Indofood menguasai begitu besar di pasar mie instant, tetapi jenis produk ini masih tetap menarik minat pengusaha untuk berkompetisi guna meraih konsumen di pasar terkait. Dominasi pasar mie instant yang besar dari Indofood dapat disinyalir menjurus kepada monopolistik.

\section{Simpulan}

Suatu tatanan ekonomi yang didominasi monopoli merupakan suatu yang berlawanan dengan prinsip untuk keuntungan sosial sebanyak-banyaknya yang diusulkan agar dicapai oleh suatu negara Islam. Karena itu, suatu negara Islam seharusnya mengutuk jenis tatanan ekonomi seperti ini dan harus dapat mengendalikan monopoli, baik dengan membuat undang-undang atau dengan perencanaan ekonomi secara menyeluruh. Perlu di catat disini bahwa dalam beberapa kegiatan (yaitu perusahaan-perusahaan pelayanan masyarakat) mungkin monopoli tidak bertentangan dengan jiwa Islam, karena persaingan dapat menyebabkan terjadinya pemborosan sumber daya.

Pada dasarnya Islam membolehkan praktik monopoli. Namun melarang praktik ikhtikar, terutama praktik ikhtikar pada bahan makanan pokok. Di sini terlihat jelas betapa pentingnya peran pemerintah untuk menekan monopoli, dengan melakukan berbagai upaya menghilangkan penimbunan (misalnya dengan penegakan hukum) bahkan juga dengan intervensi harga, sehingga harga di pasar menjadi stabil.

\section{Daftar Pustaka}

Abdurrahman, Ash-Shadiq, Fatwa-fatwa Muamalah Kontemporer, Surabaya: Pustaka Progressif, 2004

Ibrahim, Johny, cet.3.Hukum Persaingan Usaha Filosofi, Teori dan Implikasi Penerapannya di Indonesia. Malang: Bayu Media Publishing, 2009 
Kian Gie, Kwik, Saya bermimpi jadi konglomerat, Jakarta: PT.Gramedia, 1994

Kamal Rokan, Mustafa, cet. 1. Hukum Persaingan Usaha (Teori dan Praktiknya di Indonesia), Jakarta: Rajawali Press, 2010

Harun, Nasroen, Fiqh Muamalah, Jakarta: Gaya Media Pratama, 2000

Murhaini, Suriansyah, Hukum Persaingan Usaha (Perjanjian dan Kegiatan yang Dilarang dalam Hukum Persaingan Usaha di Indonesia), Yogyakarta: Aswaja Press, 2013

Adi Nugroho, Susanti, Hukum Persaingan Usaha di Indonesia (Dalam Teori dan Praktik serta Penerepan Hukumnya), Jakarta: Kencana, 2012

Qardhawi, Yusuf,cet- 4. Norma dan Etika Ekonomi Islam (Terjemahan), , Jakarta: Gema Insani Press, 2001

_. Peran Nilai dan Moral dalam Perekonomian Islam (Terjemahan), Jakarta: Robbani Press, 1997

http://hndwibowo.blogspot.com/2008/06/monopoli-dalam-pandangan-islam.html 